\title{
E-Marketplace Development With C2C Model And Appreciative Inquiry
}

\author{
B. A. Herlambang ${ }^{1}$, M . S. Zuhri ${ }^{2}$, D. Nuvitalia ${ }^{3}$ \\ ${ }^{1}$ Program Studi Informatika,FTI, Universitas PGRI Semarang \\ Jl. Sidodadi Timur No. 24 Semarang, e-mail: bambangherlambang@upgris.ac.id \\ ${ }^{2}$ Program Studi Pendidikan Matematika, FPMIPATI Universitas PGRI Semarang \\ Jl. Sidodadi Timur No. 24 Semarang, e-mail: saifuddinzuhri@upgris.ac.id \\ ${ }^{3}$ Program Studi Pendidikan fisika, FPMIPATI Universitas PGRI Semarang \\ JI. Sidodadi Timur No.24 Semarang, e-mail: nuvitalias@upgris.ac.id
}

\section{ARTICLE INFO}

Article history:

Received 22 November 2017

Received in revised form 22 November 2017

Accepted 13 December 2017

Available online 25 Januari 2017

\section{ABSTRACT}

People's lifestyles change in spending their funds have changed. Trend of software development innovation in Indonesia could be mapped into several types of E-Commerce, Media, Transportation, Accommodation and Logistics and Education. Now, there are 45 young entrepreneurs at the University PGRI Semarang. They need a tool to maximize business transactions, so it is necessary to develop E-Marketplace. The E-Marketplace Application System will be integrated with the Apprecitive Inquiry concept to reward users who frequently perform activities on the E-Marketplace application system. UML (Unifield Modeling Language) was used as a tool in designing this system. The result of this research is E-Marketplace application system that can run on web and mobile (hybrid) platform so it is expected to be a new marketing tool for young entrepreneurs at UPGRIS.

Keywords: E-Marketplace, B2C, Appreciative Inquiry, Entrepreneurship

\section{Pendahuluan}

Perubahan pola hidup masyarakat dalam membelanjakan dana yang dimiliki telah berubah. Trend inovasi pengembangan software saat ini di Indonesia saat ini dapat dipetakan menjadi beberapa jenis yaitu E-Commerce, Media, Transportasi, Akomodasi dan Logistik serta Pendidikan. Segment E-Comemerce menduduki peringkat pertama dengan jumlah terbanyak sistem aplikasi yang berkembang [1]. Industri E-Commerce Indonesia dalam sepuluh tahun terakhir tumbuh $17 \%$ dengan total jumlah usaha E-Commerce mencapai 26,2 juta unit [2]. Data analisis Ernst \& Young, dapat dilihat pertumbuhan nilai penjualan bisnis online di tanah air setiap tahun meningkat 40 persen. Ada sekitar 93,4 juta pengguna internet dan 71 juta pengguna perangkat telepon pintar di Indonesia [3].

E-Commerce didefinisikan sebagai semua bentuk proses pertukaran informasi antara organisasi dan stakeholder berbasiskan media elektronik yang terhubung ke jaringan internet. Dalam E-Commerce terdapat model transaksi C2C (Customers to Customers) yang merupakan bagian dari E-Commerce yang menekankan kepada 
proses pemesanan, pembelian, dan penjualan produk atau jasa antara penjual dan pembeli langsung melalui akses internet [4]. Salah satu jenis E-Commerce adalah E-Marketplace, yang dapat didefinisikan sebagai tempat untuk berjualan online dengan pengelolaan oleh satu pihak, produk dan informasi produknya disediakan oleh pihak lain [5]. Universitas PGRI Semarang merupakan salah satu universitas yang mengembangkan kewirausahaan bagi para mahasiswanya. Hal ini diimplementasikan dengan menerapkan mata kuliah kewirausahaan dengan beban 2 SKS dalam kurikulum yang ada pada tiap program studi. Dengan adanya kurikulum mata kuliah kewirausahaan diharapkan mahasiswa selain memiliki kemampuan dalam bidang akademis tentunya akan memiliki kemampuan soft skill sehingga saat lulus mahasiswa tidak hanya sebagai pencari kerja tapi diharapkan juga dapat menyediakan lapangan kerja. Saat ini kurang lebih telah terdapat 45 wirausaha muda yang ada pada Universitas PGRI Semarang. Dalam menjalankan transaksi usaha para wirausaha muda yang merupakan mahasiswa masih mengandalkan sistem dari mulut ke mulut dan media sosial untuk mengenalkan dan memasarkan produk atau jasa mereka.

Sebagai wadah dan sarana untuk lebih memaksimalkan transaksi usaha penjualan bagi para wirausaha muda tersebut maka perlu dikembangkan E-Marketplace. Sistem Aplikasi EMarketplace yang dikembangkan akan dipadukan dengan konsep Apprecitive Inquiry untuk memberikan penghargaan pada para user yang sering mengakses E-Marketplace. Apprecitive Inquiry adalah suatu konsep dalam penelitian perilaku yang berfokus pada penghargaan dari sesuatu yang positif. Umumnya Apprecitive Inquiry diterapkan dalam suatu organisasi dan berangkat dari kelebihan dan kekuatan yang dimiliki. Penelitian yang berkaitan dengan Apprecitive Inquiry antara lain mengembangkan Appreciative Inquiry sebagai suatu model pembelajaran [6]. E-Marketplace yang dikembangkan dapat berjalan pada platform web dan mobile (hybrid) sehingga diharapkan mampu menjadi sebuah sarana pemasaran produk yang baru bagi para wirausaha muda UPGRIS.

\section{Metode Penelitian}

Dalam penelitian ini akan dikembangkan sistem E-Marketplace dengan model C2C dan Appreciative Inquiry untuk Wirausaha Muda pada Universitas PGRI Semarang. Metode yang digunakan dalam pengumpulan data untuk membangun E-Marketplace ini antara lain:

1. Observasi

Melakukan pengamatan langsung pada aplikasi e-marketplace yang telah ada untuk mengetahui desain user interface, jenis produk yang ditawarkan dan model bertransaksi.

2. Studi Pustaka

Mengumpulkan kebutuhan data tentang perkembangan e-commerce, konsep appreciative inquiry dari buku, jurnal dan artikel ilmiah untuk mendapatkan pengetahuan konsep dari penelitian ini.

3. Survei

Melakukan survei kepada para wirausaha muda UPGRIS berkaitan dengan jenis produk yang dimiliki untuk kebutuhan desain menu aplikasi serta beberapa pengguna layanan EMarketplace untuk mengetahui kelebihan dan kekurangan dalam bertransaksi dengan EMarketplace.

Tahapan pengembangan sistem yang dilakukan dalam penelitian ini menggunakan model Waterfall [6]. Adapun langkah dalam pengembangan sistem dapat digambarkan sebagai berikut: 


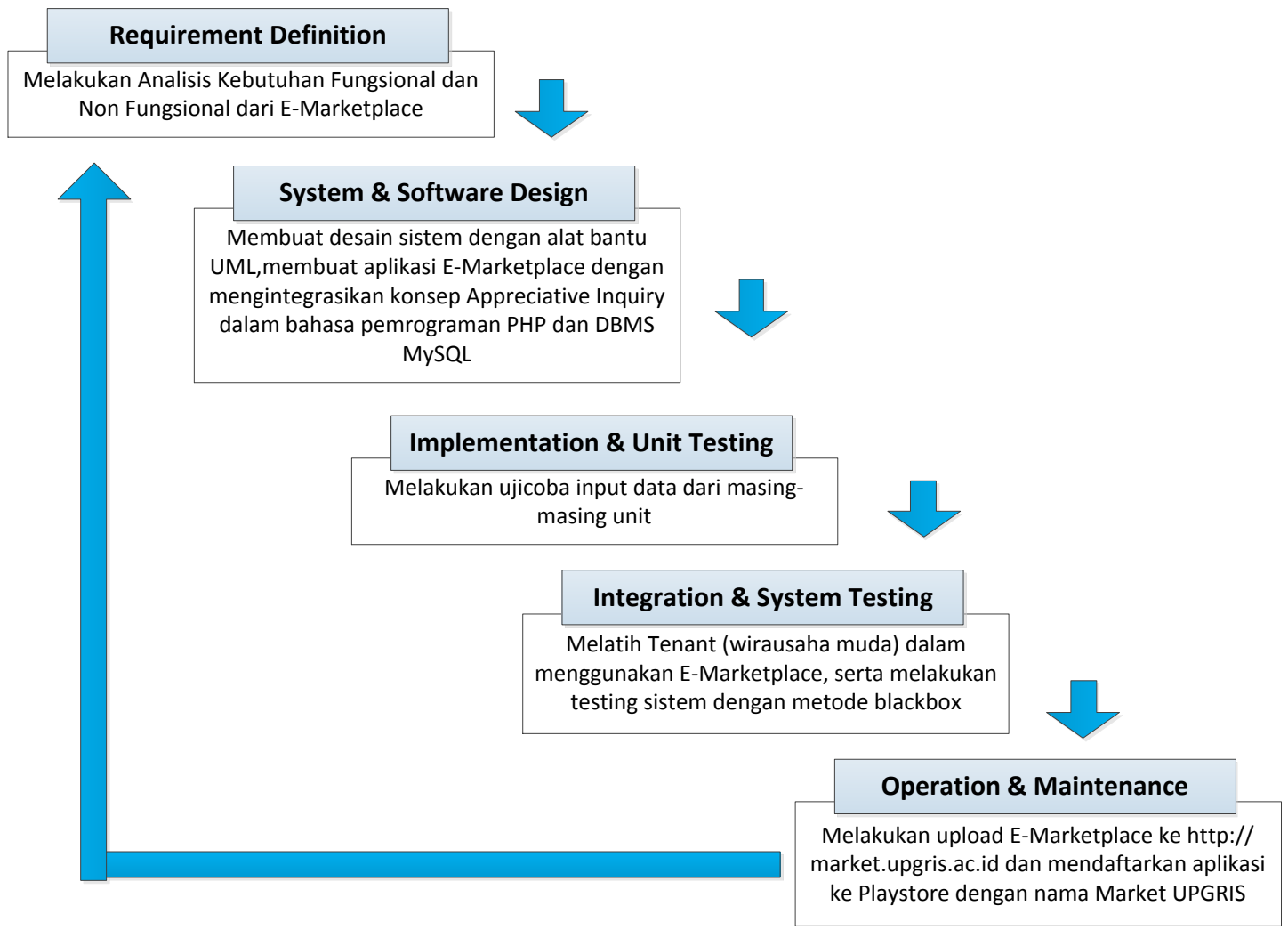

Gambar 1: Tahapan Pengembangan Sistem

\section{Analisis dan Hasil}

\subsection{Desain Sistem}

Tahapan pertama yang dilakukan dalam pengembangan E-Marketplace adalah Requirement Definition. Dalam tahapan ini dilakukan identifikasi terhadap kebutuhan fungsional dan non fungsional dari E-Marketplace sehingga memiliki kelebihan bagi penjual yaitu penghematan biaya operasioanal serta dapat menyajikan informasi produk dengan lebih mudah tanpa batasan waktu [7]. Kebutuhan fungsional dari E-Marketplace yang dibangun antara lain dapat mengakomodir registrasi data tenant, data produk,serta lokasi tenant yang terintegrasi dengan Google Map API. Kebutuhan Non Fungsional dalam E-Marketplace ini antara lain kebutuhan hardware sebagai server dan hardware client, kebutuhan software untuk membangun aplikasi sehingga aplikasi dapat berjalan pada platform web ataupun mobile (hybrid). Tahapan selanjutnya yang dilakukan adalah membuat desain dan sistem aplikasi E-Marketplace. Dalam membuat desain ini digunakan alat bantu perancangan sistem UML (Unifield Modeling Language) yang merupakan alat bantu perancangan sistem dengan pendekatan beroientasi objek [8]. Adapun desain dari Use Case Diagram dalam E-Marketplace ini adalah sebagai berikut: 


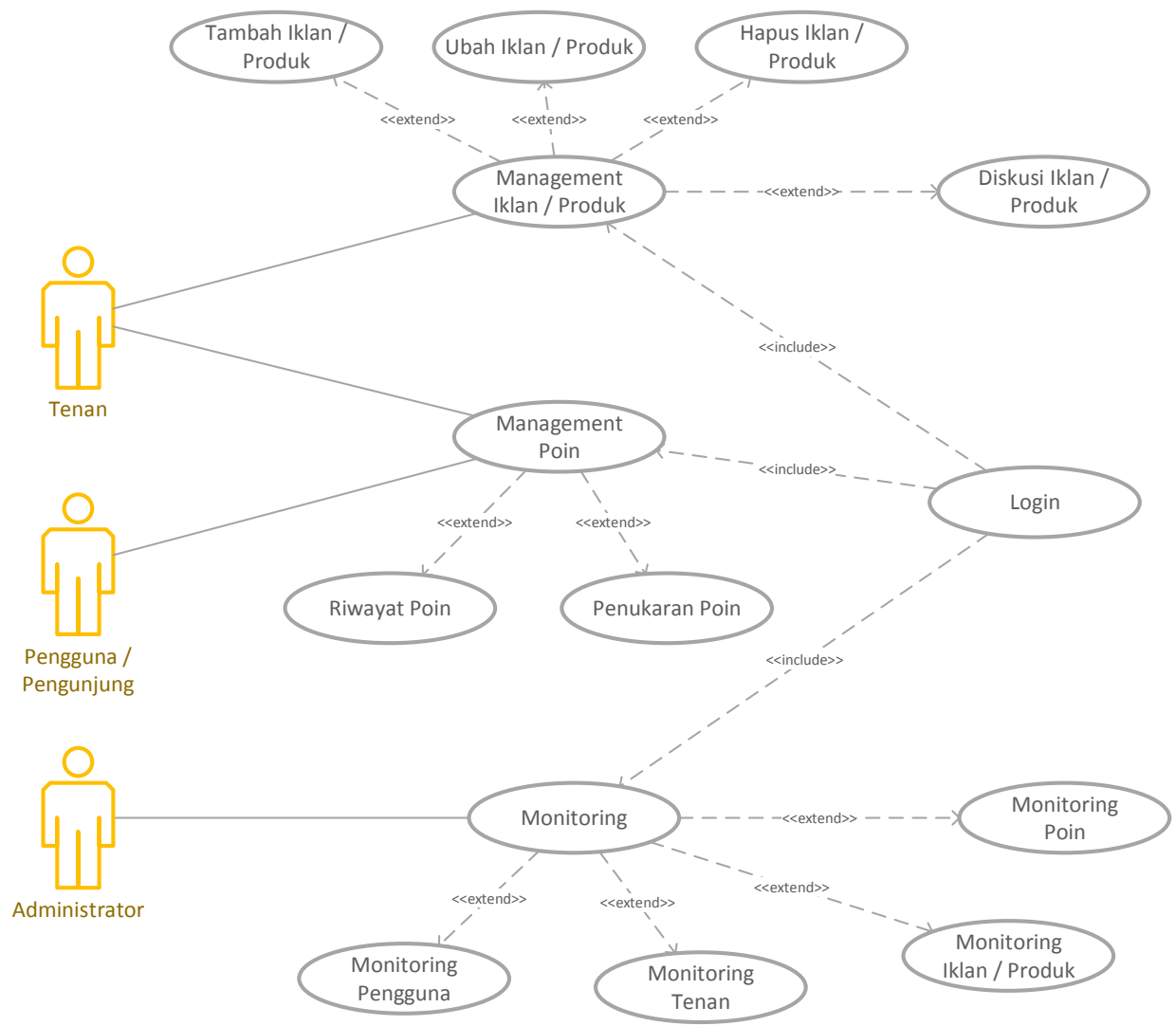

Gambar 2: Use Case Diagaram

Dalam use case diagram diatas terlihat 3 (tiga) aktor yaitu tenant,pengguna/pengunjung dan administrator yang terlibat dalam sistem ini dengan peran masing-masing. Tenant dapat melakukan manajemen produk (tambah,edit,hapus) setelah melakukan login. Pengguna/Pengunjung dapat melakukan manajemen point. Administrator mempunyai peran dalam hal monitoring pengguna, tenant,produk dan point. Adapun bentuk tabel relasi yang ada dalam sistem aplikasi E-Marketplace ini adalah sebagai berikut: 


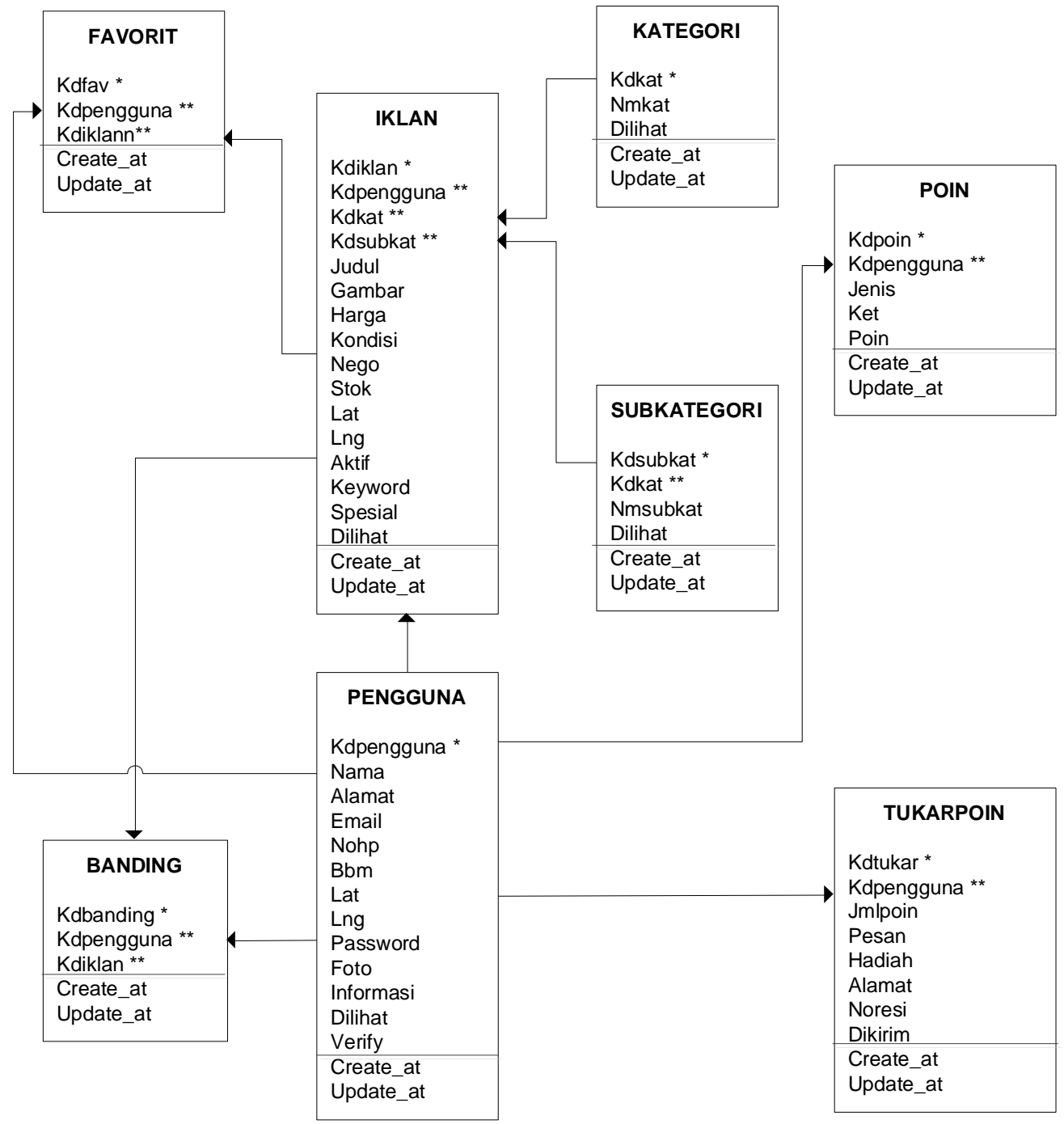

Gambar 3: Diagram Class

Desain use case diagram, activity diagram dan class diagram yang telah terbentuk kemudian diimplementasikan dalam e-marketplace dengan ditambahkan model appreciative incuiry untuk mendorong tenant untuk mengakses halaman e-marketplace ini

\subsection{Implementasi}

Adapun implementasi dari E-Marketplace yang dikembangkan dapat dilihat dalam gambar user interface sebagai berikut:

TRANSFORMATIKA Vol. 15, No.2, January 2018: 96 - 105 


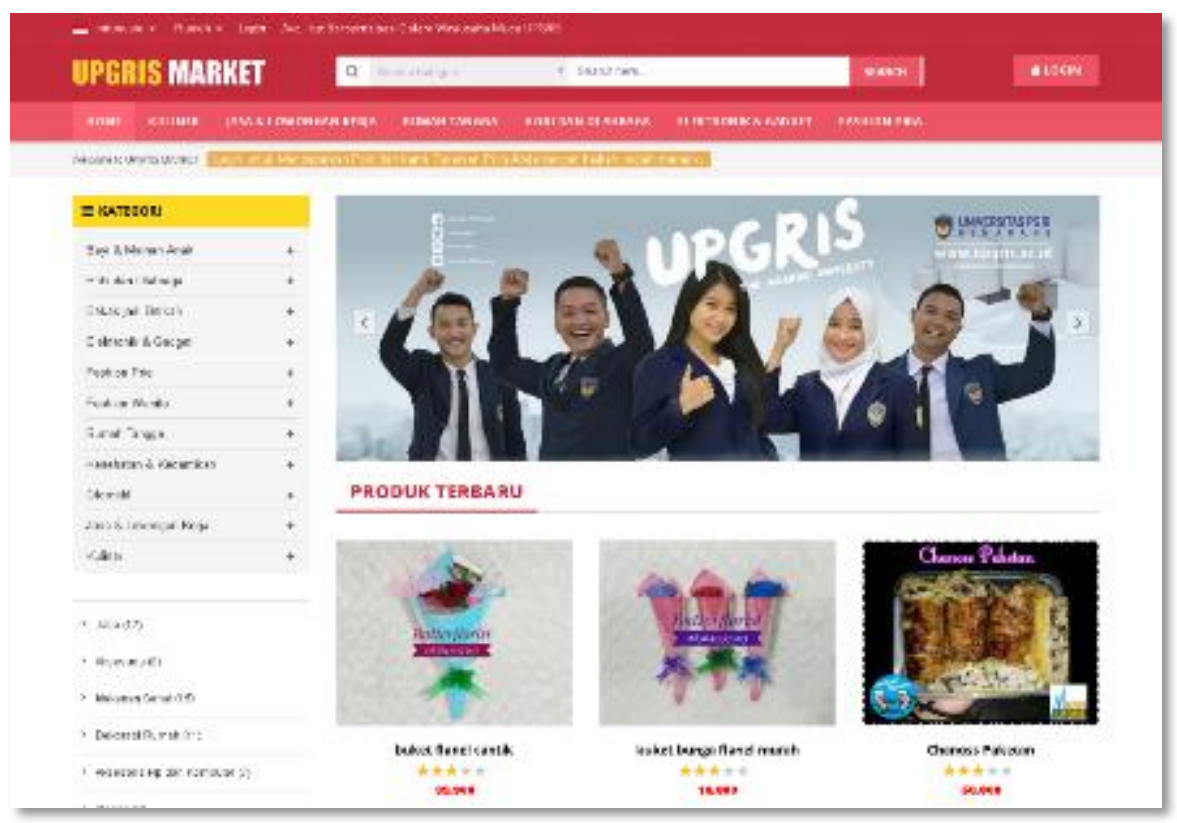

Gambar 4: Halaman Utama

Gambar tampilan diatas merupakan halaman utama dari e-market, dalam halaman utama yang telah disesain terlihat beberapa menu kategori produk yang dapat dipilih oleh user, produkproduk kategori terpopuler, preview gambar produk untuk mempermudah pembeli melihat barang yang ada dalam e-market UPGRIS.

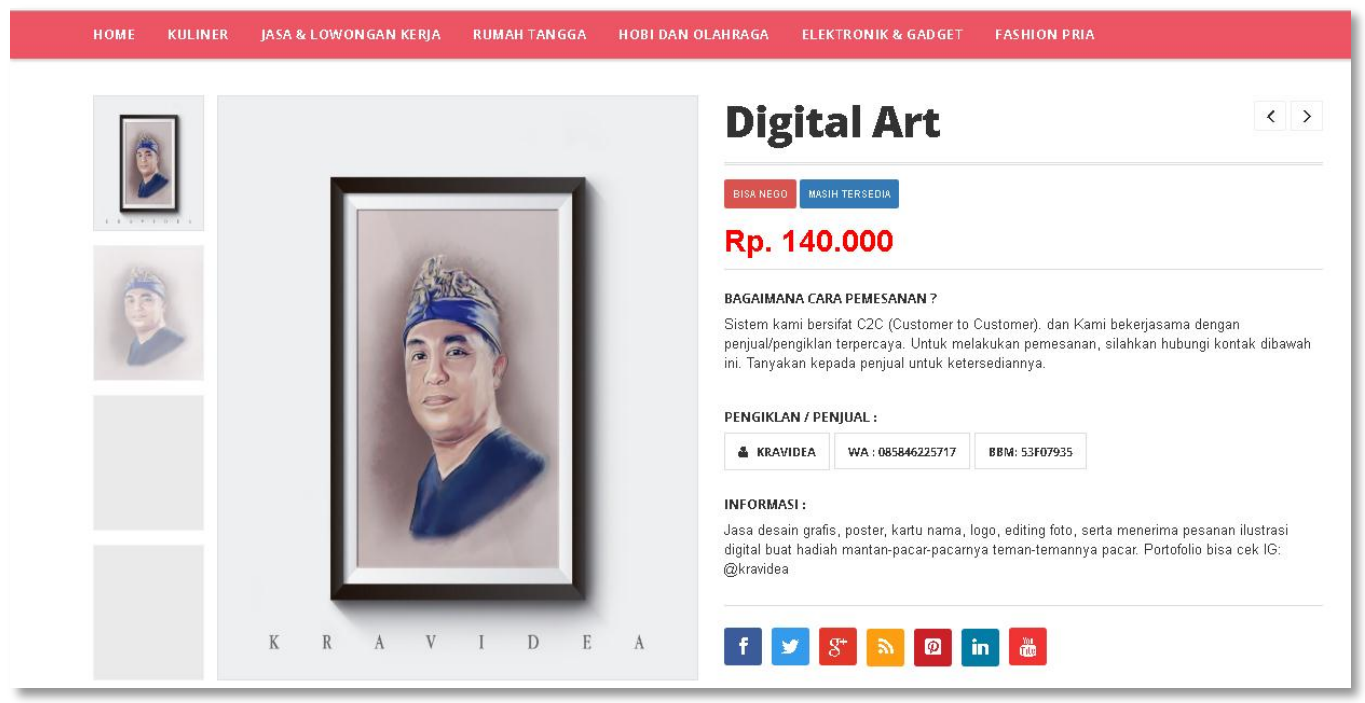

Gambar 5: Halaman Detail Produk

Gambar tampilan diatas merupakan gambar detai produk ketika tombol lihat produk pada halaman utama diklik. Dalam halaman ini akan terdapat gambar produk, harga produk dan kontak penjual/ produsen. Pembeli dapat langsung melakukan transaksi dengan penjual/ produsen dari produk barang atau jasa yang diinginkan. 
Pada halaman utama terdapat tombol untuk login registrasi tenant dan user melakukan transaksi pembelian tersedia dalam halaman utama ini. Untuk registrasi sebagi tenant harus melakukan pendaftaran dengan meng-klik tombol login sehingga muncul tampilan berikut ini:

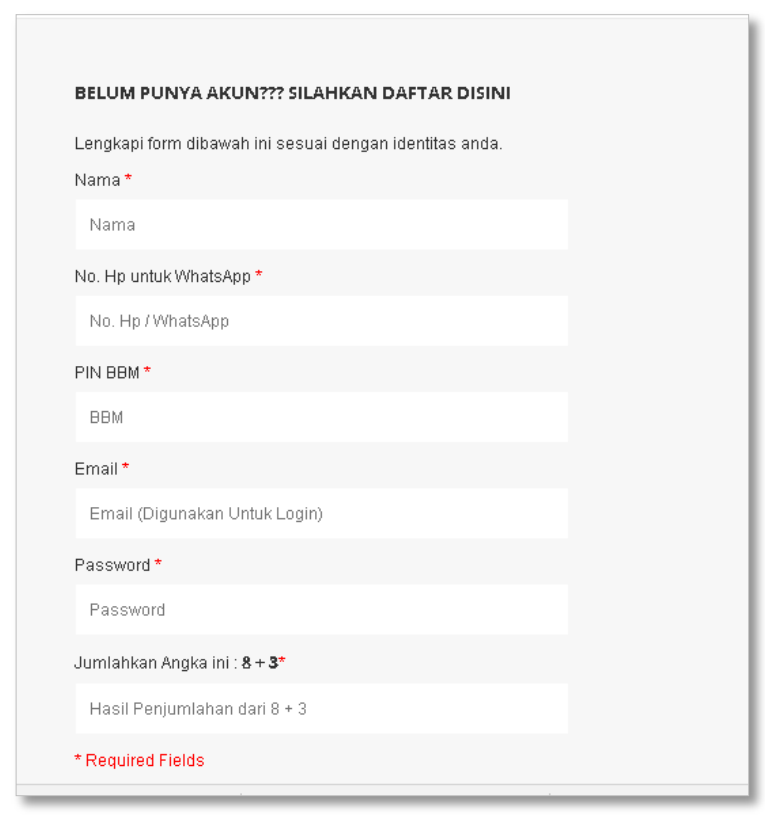

Gambar 5: Form Login

Setelah melakukan login bagi tenant diwajibkan untuk melukan verifikasi untuk dapat mengelola beberapa halaman antara lain penglolaan iklan produk, pengelolaan point. Berikut beberapa halaman yang dapat dikelola oleh tenat setelah melakukan verifikasi:

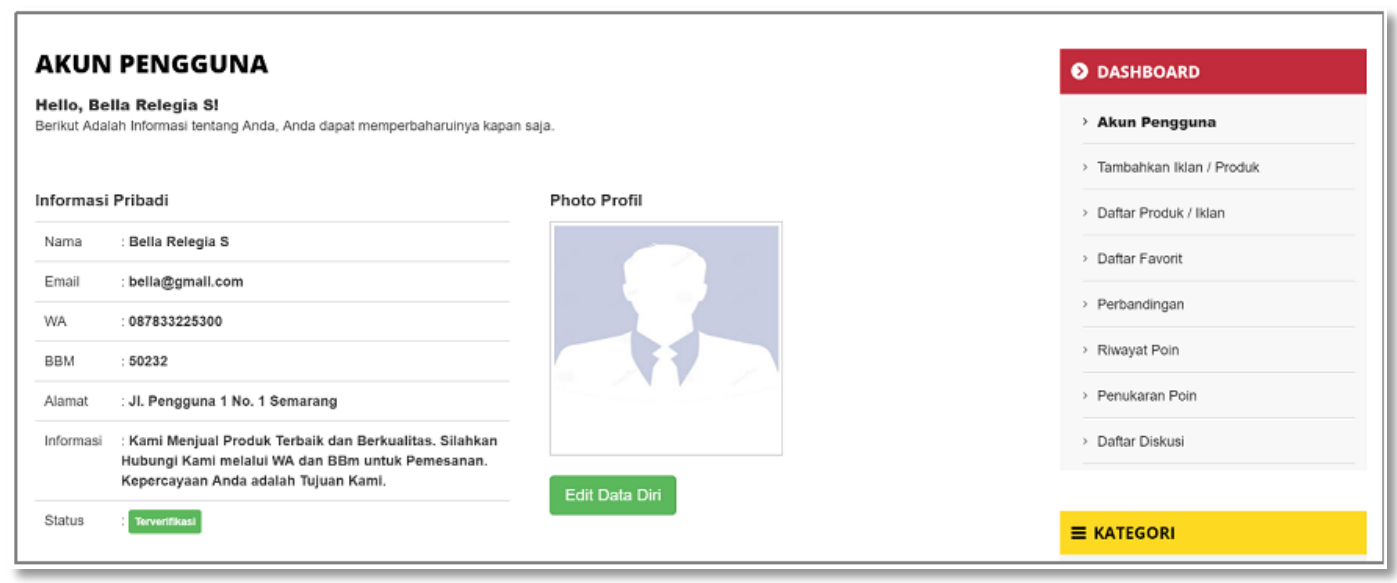

Gambar 6: Halaman Dashboard Tenant

Halaman diatas merupakan halaman dashboard bagi tenant, dalam halaman ini tersedia beberapa menu antara lain tambah iklan/produk,daftar produk,daftar favorit, riwayat point, penukaran point dan daftar diskusi.

TRANSFORMATIKA Vol. 15, No.2, January 2018: 96 - 105 


\section{MY POIN}

Hello, Bella Relegia S! Ini adalah $\mathrm{F}$
dari kami.

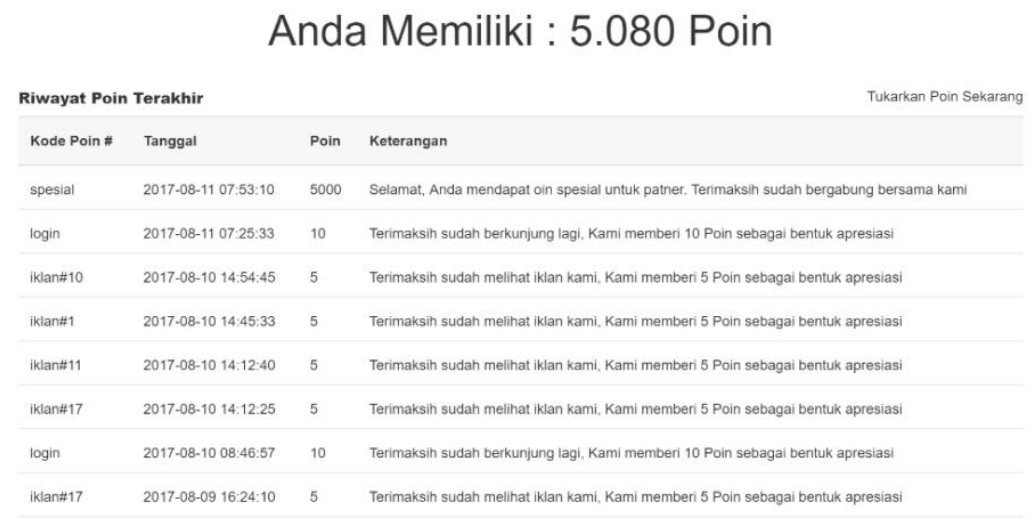

Gambar 7: Pengelolaan Point

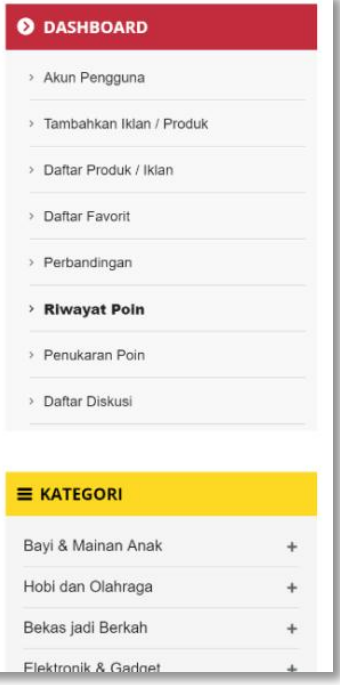

\section{(2) DAshboard}

Flektronik \& Gadae

Gambar tampilan diatas merupakan implementasi dari model Appreciative Inquiry dalam Emarketpace ini adalah tiap tenant yang melakukan berbagai aktivitas dalam halaman EMarketplace ini tenant akan mendapatkan point setiap melakukan tindakan dalam sistem aplikasi. Setiap user melakukan registrasi akan mendapatkan 20 point, login akan mendapatkan point 10/hari, user melakukan update produk yang ditawarkan akan mendapatkan point 5 point/hari/produk dan spesial point yang ditentukan oleh admin. Minimal point yang dpat ditukarkan untuk reward adalah 5000 point. Point yang telah didapatkan tenant akan dapat ditukar dengan reward yaitu dengan pemasangan iklan banner promosi produk tenant pada halaman utama e-market selama 1 bulan, produk tenant dapat tampil pada halaman terdepan serta mendapatkan tanda sebagai produk terlaris. Setelah poin terkumpul minimal 5000 Poin, tenatg dapat menukarkan poin tersebut dengan hadiah menarik dengan mengisi form penukaran poin seperti gambar dibawah ini:

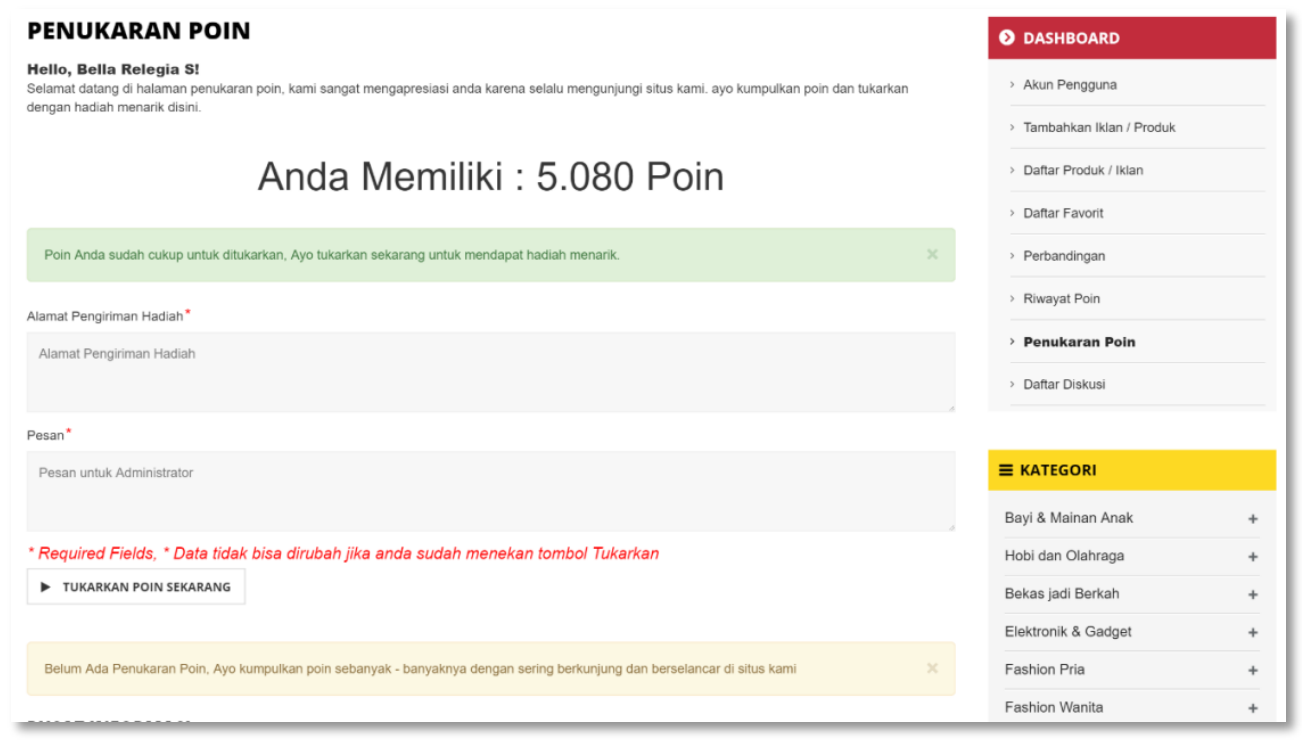

Gambar 8: form Penukaran Point 


\subsection{Pengujian}

Pengujian yang digunakan untuk menguji program adalah pengujian internal. Untuk pengujian internal dengan mengecek black box dengan input klik icon maupun button dan output tampilan halaman yang diklik apakah dapat berfungsi dengan baik atau tidak. Dengan pengujian black box pada proses login E-Marketplace diharapkan diketahui validitas form dalam menerima inputan. Pengujian login dilakukan dengan memasukkan user name password jika tidak sesuai maka tampil pesan peringatan dan pemakai tidak dapat akses kedalam sistem tersebut

Tabel 1: Pengujian Inputan

\begin{tabular}{|c|c|c|c|}
\hline \multicolumn{4}{|c|}{ Kasus dan Hasil Pengujian (Data benar) } \\
\hline $\begin{array}{c}\text { Data } \\
\text { Masukan }\end{array}$ & Yang diharapkan & Pengamatan & Kesimpulan \\
\hline $\begin{array}{l}\text { Data User } \\
\text { yang } \\
\text { sebelumnya } \\
\text { telah terdaftar } \\
\text { di sistem }\end{array}$ & $\begin{array}{l}\text {.User dapat masuk ke } \\
\text { dalam dashboard dan } \\
\text { melakukan verifikasi }\end{array}$ & $\begin{array}{l}\text { Dapat menampilkan } \\
\text { dashboard }\end{array}$ & $\begin{array}{l}\text { [X] Diterima } \\
\text { [ ] Ditolak }\end{array}$ \\
\hline $\begin{array}{l}\text { Kode } \\
\text { Verifikasi }\end{array}$ & $\begin{array}{l}\text { User dapat melakukan } \\
\text { pengelolaan halaman } \\
\text { dashbosrd }\end{array}$ & $\begin{array}{l}\text { User dapat melakukan input } \\
\text { data produk }\end{array}$ & $\begin{array}{l}\text { [X] Diterima } \\
\text { [ ] Ditolak }\end{array}$ \\
\hline $\begin{array}{l}\text { Upload } \\
\text { Gambar } \\
\text { Produk } \\
<2 \mathrm{Mb}\end{array}$ & $\begin{array}{l}\text { Data masuk kedalam } \\
\text { sistem }\end{array}$ & $\begin{array}{l}\text { Gambar Masuk Kedalam } \\
\text { etalase produk }\end{array}$ & $\begin{array}{l}\text { [X] Diterima } \\
\text { [ ] Ditolak }\end{array}$ \\
\hline
\end{tabular}

\begin{tabular}{|c|c|c|c|}
\hline \multicolumn{4}{|c|}{ Kasus dan Hasil Pengujian (Data Salah) } \\
\hline $\begin{array}{c}\text { Data } \\
\text { Masukan }\end{array}$ & $\begin{array}{c}\text { Yang } \\
\text { diharapkan }\end{array}$ & Pengamatan & Kesimpulan \\
\hline Data User & $\begin{array}{l}\text { Input User } \\
\text { sebelumnya } \\
\text { berlum } \\
\text { terdaftar di } \\
\text { sistem }\end{array}$ & $\begin{array}{l}\text { User tidak dapat login ke halaman } \\
\text { dahboard dan muncul pesan } \\
\text { kesalahan }\end{array}$ & $\begin{array}{l}\text { [X] Diterima } \\
\text { [ ] Ditolak }\end{array}$ \\
\hline $\begin{array}{l}\text { Kode } \\
\text { Verifikasi }\end{array}$ & $\begin{array}{l}\text { Muncul pesan } \\
\text { kesalahan dan user } \\
\text { tidak dapat } \\
\text { melakukan } \\
\text { pengelolaan } \\
\text { halaman dashbosrd }\end{array}$ & $\begin{array}{l}\text { User tidak dapat melakukan input } \\
\text { data produk dan terdapat pesan } \\
\text { kesalahan kode verifikasi }\end{array}$ & $\begin{array}{l}\text { [X] Diterima } \\
\text { [ ] Ditolak }\end{array}$ \\
\hline $\begin{array}{l}\text { Upload } \\
\text { Gambar } \\
\text { Produk }>2 \mathrm{Mb}\end{array}$ & $\begin{array}{l}\text { Data tidak } \\
\text { dapat masuk } \\
\text { kedalam } \\
\text { sistem }\end{array}$ & $\begin{array}{l}\text { Gambar tidak dapat masuk dan tampil } \\
\text { kedalam etalase produk }\end{array}$ & $\begin{array}{l}\text { [X] Diterima } \\
\text { [ ] Ditolak }\end{array}$ \\
\hline
\end{tabular}

\section{Kesimpulan dan Saran}

E-Marketplace telah dapat dikembangkan dengan model Costomers to Customers dimana sistem aplikasi ini hanya sebagai tempat memasarkan/ promosi produk barang atau jasa tenant sedangkan proses transaksi dan pembayaran langsung dilakukan oleh customer dan pemasang produk dalam sistem E-marketplace ini. Sistem aplikasi ini merupakan fasilitas bagi wirausaha

TRANSFORMATIKA Vol. 15, No.2, January 2018: 96 - 105 
muda dan alumni Universitas PGRI Semarang untuk memasarkan dan menjual produk barang atau jasa yang dimilikinya. Implementasi model Appreciative Inquiry diterapkan dalam Emarketplace ini yaitu dengan menerapkan sistem point untuk setiap tindakan yang dilakukan user/ tenant dalam sistem ini. Hal ini dimaksudkan agar lebih memberikan semangat bagi user/ tenant untuk melakukan update barang atau jasa. Penetilan kedepan dapat dilakukan dengan mengevaluasi produk yang sering dilihat dan dicari dalam sistem E-Marketplace ini serta pengembangan fitur keamanan dalam E-marketplace ini.

\section{Referensi}

[1] R. S. Wahono, "Gap dan Solusi Akademisi-Technopreuner," 2017.

[2] "http://tekno.liputan6.com," [Online]. Available: http://tekno.liputan6.com/read/2957050/pertumbuhan-e-commerce-indonesia-tertinggi-didunia. [Diakses 25 Agustus 2017].

[3] "https://kominfo.go.id/index.php/content/detail/6441/Indonesia+Akan+Jadi+Pemain+Ekon omi+Digital+Terbesar+di+Asia+Tenggara/0/berita_satker/," [Online]. Available: https://kominfo.go.id/index.php/content/detail/6441/Indonesia+Akan+Jadi+Pemain+Ekono mi+Digital+Terbesar+di+Asia+Tenggara/0/berita_satker/. [Diakses 25 Agustus 2017].

[4] E. Pratama, Sistem Informasi dan Implementasinya. Bandung:, Bandung: Informatika, 2014.

[5] K. Uladzimir Radkevitch, Leveraging Offshore IT Outsourcing by SMEs through Online Marketplaces, Rotterdam, 2006.

[6] R. Yee Leng Eow, “Appreciative Learning Approach : A New Pedagogical Option,” dalam International Conference On Computers In Education, Putrajaya, 2010.

[7] P. Roger S. Pressman, Rekayasa Perangkat Lunak Pendekatan Praktisi, Yogyakarta: Andi, 2002.

[8] K. Chris Rowley, Electronic-Marketplaces And Their Evolving Benefits Over Time, 2009.

[9] J. Hermawan, Analisa Desain \& Pemrograman Berorientasi Obyek dengan UML dan Visual Basic.Net, Jakarta: Andy Publisher, 2005. 